\title{
Unequal Expression of Allelic Kainate Receptor GluR7 mRNAs in Human Brains
}

\author{
Hans H. Schiffer, ${ }^{1}$ Geoffrey T. Swanson, ${ }^{1}$ Elizier Masliah, ${ }^{2}$ and Stephen F. Heinemann ${ }^{1}$ \\ ${ }^{1}$ Molecular Neurobiology Laboratory, Salk Institute for Biological Studies, La Jolla, California 92037, and 2Department of \\ Neurosciences, University of California, San Diego, La Jolla, California 92039-0624
}

\begin{abstract}
We describe here the first example of an exonic polymorphism that affects the primary structure of a human ionotropic glutamate receptor. The human kainate receptor GluR7 gene contains a thymine $(\mathrm{T})$ /guanine $(\mathrm{G})$ nucleotide variation that determines a serine or alanine at position 310 in the extracellular region of GluR7 receptor subunits. Our finding contrasts with a previous report that suggested that GluR7 transcripts were RNA-edited at this site. Whole-cell patch-clamp recordings did not detect differences in receptor activation and desensitization between the human GluR7 receptor isoforms expressed in HEK-293 cells. Analysis of 41 tissue samples obtained from 30 human brains revealed expression level differences between GluR7 alleles ex-
\end{abstract}

pressed in the same brain. The expression level of the allelic GluR7 mRNAs differed in 27 samples from 1.2- to 12.7-fold. Unequal expression level of allelic mRNAs is characteristic for genes that are affected by genomic imprinting or that contain mutations. Genomic imprinting in most cases is conserved between human and mice. However, we did not detect unequal expression of allelic GluR7 mRNAs in mice. Our results are important for future studies that explore a potential role or roles for GluR7 receptors in the brain and for neurological disorders.

Key words: kainate receptor; GluR7; polymorphism; allele expression; genomic imprinting; RNA editing
Ionotropic glutamate receptors mediate excitatory synaptic transmission in the mammalian CNS and play a central role in learning and memory (Hollmann and Heinemann, 1994; Sprengel and Seeburg, 1995; Dingledine et al., 1999). Calcium influx through ionotropic glutamate receptors modulates numerous transcriptional, translational, and post-translational mechanisms that affect the function of individual cells, brain regions, and ultimately the whole nervous system (Hollmann and Heinemann, 1994; Sprengel and Seeburg, 1995; Dingledine et al., 1999). Glutamate receptors also are thought to be involved in the pathogenesis of several neurological diseases (Choi, 1988; Coyle and Puttfarcken, 1993; McNamara, 1993). Excessive activation of glutamate receptors can cause excitotoxicity and cell death by increasing intracellular calcium concentrations for a prolonged period of time (Olney, 1980; Choi et al., 1987; Lipton and Rosenberg, 1994; Weiss et al., 1994). Although it is clear that glutamate receptors as a gene family play an important role in neurodegenerative pathology, the involvement of specific subtypes of glutamate receptors, particularly the non-NMDA receptors and the AMPA and kainate subtypes, only recently have begun to be explored fully.

Ionotropic glutamate receptors of the kainate-preferring subtype (GluR5-7, KA1, and KA2) may be involved in the genesis of glutamate-mediated excitotoxicity. RNA editing at the glutamine/ arginine $(\mathrm{Q} / \mathrm{R})$ site, which changes a glutamine to an arginine in the pore-forming region of the protein, reduces the calcium per-

\footnotetext{
Received July 14, 2000; revised Sept. 21, 2000; accepted Sept. 27, 2000.

This work was supported by a fellowship from the National Alliance for Research on Schizophrenia and Depression to G.T.S. and by grants from National Institutes of Health, the McKnight Foundation, and the John Adler Foundation to S.F.H. We thank Tim Green and Anis Contractor for helpful discussions and critical comments on this manuscript and Adi Gheva for technical assistance. We also thank Leon J. Thal and Mary Sundsmo from the Alzheimer Disease Research Center (ADRC) at the University of California, San Diego; E. Fuller Torrey from the Stanley Foundation at the National Alliance for the Mentally Ill Research Institute (Bethesda, MD); and Jeff Mann from the Beckman Research Institute of the City of Hope (Duarte, CA) for their support of this project. We are grateful to Juan Carlos de la Torre at the Scripps Research Institute (San Diego, CA). The human GluR7 cDNA clone was kindly provided by Lorrie Daggett, Merck Research Laboratories (San Diego, CA). The Core Sequencing Facility at the Salk Institute performed the DNA sequencing.

Correspondence should be addressed to Dr. Hans H. Schiffer, Molecular Neurobiology Laboratory, Salk Institute for Biological Studies, 10010 North Torrey Pines Road, La Jolla, CA 92037. E-mail: schiffer@salk.edu.

Copyright (C) 2000 Society for Neuroscience $0270-6474 / 00 / 209025-09 \$ 15.00 / 0$
}

meability of GluR2, GluR5, and GluR6 receptors (Seeburg, 1996). Although GluR2 undergoes essentially complete editing very early on in development, a significant percentage of GluR5 and GluR6 subunits is unedited (and therefore potentially calcium-permeable) throughout development and into adulthood (Seeburg, 1996). GluR7 receptors contain a glutamine at the $\mathrm{Q} / \mathrm{R}$ site and do not undergo RNA editing, suggesting that this receptor subunit remains calcium-permeable. All of these receptor subunits have high affinity for excitotoxic compounds such as kainic acid and are among the primary targets of such neurotoxins (Hollmann and Heinemann, 1994; Dingledine et al., 1999). Direct evidence recently has emerged for this hypothesis from studies on GluR6 knock-out mice, which are more resistant to kainate-induced seizures and excitotoxic cell death in the hippocampus (Mulle et al., 1998).

We previously described the functional properties of homomeric and heteromeric rat GluR7 kainate receptors (Schiffer et al., 1997) and were interested in exploring the physiological consequences of putative novel RNA-editing sites in the human GluR7 subunit (Nutt et al., 1994). However, we report here that the exonic nucleotide variation in the GluR7 cDNA arises from polymorphic GluR7 genes in the human gene pool and not from RNA editing, as proposed previously. Polymorphisms in genes are useful for genetic studies that try to relate a gene to a disease. Therefore, we were interested to characterize the $\mathrm{T} / \mathrm{G}$ polymorphism in the human GluR7 gene in more detail. In particular, we studied the allele frequency and genotype distribution of the polymorphism in the human population and compared the pharmacology and receptor kinetics of the GluR7 receptor isoforms that are encoded by polymorphic GluR7 genes. Additionally, we tested whether the GluR7 gene is affected by genomic imprinting.

\section{MATERIALS AND METHODS}

Source of DNA and RNA samples. The rat genomic DNA (\#6750-1), rat total RNA (\#64060-1), human genomic DNA (\#6550-1), and human total RNA (\#64020-1) that were used in the experiments described in Figure 1 were obtained from Clontech (Palo Alto, CA). Genomic DNA and brain total RNA from neuropsychiatric disorder cases were isolated from brain tissue samples kindly provided by the Stanley Foundation at the National Alliance for the Mentally Ill Research Institute (NAMI, Bethesda, MD). The human genomic control DNAs used for the estimation of GluR7 allele frequency and genotype distribution in the group of Caucasian people (Table 1) were obtained from the Alzheimer Disease Research Center at 
Table 1. Frequency of the GluR7 $\mathrm{T}$ and $\mathrm{G}$ allele and genotype distribution of the GluR7 T/G polymorphism in 35 Caucasians

Genotype (\%)

$\begin{array}{lc}\mathrm{T} / \mathrm{T}, n & 17(48.6 \%) \\ \mathrm{T} / \mathrm{G}, n & 15(42.8 \%) \\ \mathrm{G} / \mathrm{G}, n & 3(8.6 \%) \\ \text { Allele frequency } & \\ \mathrm{T} & 0.70 \\ \mathrm{G} & 0.30\end{array}$

Genomic PCR fragments that cover the T/G site of the human GluR7 gene were obtained from 35 genomic DNA samples (Caucasian) and genotyped by using the cycled primer extension assay (see Materials and Methods). $n=35$.

the University of California, San Diego. E. Masliah from the Department of Neurosciences, University California, San Diego, provided all other human brain tissue samples.

Primers used to analyze nucleotide variation in rat, human, and mouse GluR7 genes and mRNAs. Rat GluR7 cDNA synthesis was initiated with the gene-specific primer R7.3170 (GATGAAGCCCAAGCAGCTGCTGAGGGC). Rat genomic DNA products covering either the $T / G$ site or the $\mathrm{G} / \mathrm{A}$ site were amplified by using the following primer pairs, respectively: primer R7.890 (GAATACTACCACTTCATCTTCACC) and primer R7.1095 (CATCACTCCAT-CCAGCAGGCCTGACT) or primer R7.1110 (GCAGCCCTGCTCTACGATGCGGTC) and primer R7.1309 (TCTTCCTTGAGGCTGATGATGTC). Rat RT-PCR fragments containing the GluR7 T/G and G/A site were amplified with the primer pair R7.890 and R7.1309. Rat genomic PCR and RT-PCR fragments were analyzed for the presence of nucleotide variation at the T/G or G/A site via the cycled primer extension assay, the radiolabeled primer R7.PE.T/G (GCGGCTACAGGCAGCTG) or R7.PE.G/A (GAAGCGCCAGGGCTTGT), and the dideoxy terminator ddTTP. Human or mouse GluR7 cDNA was synthesized on total brain RNA by using the GluR7 gene-specific primers H7.2952 (CTGGCCTGAGAGCCTGCTGGCTTC) or M7.1825 (CGGGGGAGCCTGAGAGGCATGTGC), respectively. Human genomic DNA fragments covering the $\mathrm{T} / \mathrm{G}$ site were amplified by using the primer pair H7.830 (CCTACCGCTACTCAGGCGTGAACC) and H7.430AS (TTCTTCTTTCTGCCTTCTCGGCCTT). Genomic PCR products containing the $\mathrm{C} / \mathrm{T}$ site from the mouse GluR7 gene were obtained by using the GluR7 gene-specific primer pair M7.GE.E (TCCTTCCTCAATCCCCTGTCTCCG) and M7.GE.F (ACACAGCTGACACCCAGGTAGGCA). RT-PCR fragments containing the human $\mathrm{T} / \mathrm{G}$ site were amplified by using the primer pair H7.830 (CCTACCGCTACTCAGGCGTGAACC) and H7.1110 (TTCCCATTGAGCCTCCTTGATGAAG) or the primer pair Oli4 (ATGAAGCGGCCGCCAAAGCGC) and Oli3+3 (TCAGGCGTGAACCTGACAGGATTC). RT-PCR products containing the mouse GluR7 C/T site were obtained by performing standard RT-PCR reactions with the primer pair M7.342 (GACCATCACCCATGTCCGAGAGAA) and M7.662 (GGAGCCCATTCCAAACCAGAAGCT). The T/G polymorphism identified in the human GluR7 gene and mRNA was studied by using a cycled primer extension assay with the dideoxy terminator ddTTP and the primer H7.PE.T/G (GGCTGCAGGCAGCTCCC). The C/T polymorphism that was identified in 129/ $S v E v T a c \times C B A / C a J \mathrm{~F} 1$ generation mice was analyzed by performing primer extension assays with the dideoxy terminator ddATP. The primer M7.PE.C/Ta (CGTACATCCAGATGTCC) was used for these assays.

cDNA synthesis, PCR. Total RNA and genomic DNA were prepared by using the Trizol reagent derived from Life Technologies (Rockville, MD). To avoid cross contamination, we homogenized brain tissue samples with a homogenizer and disposable generator probes obtained from Omni (Warrenton, VA). cDNA was generated by the Thermoscript RT-PCR system from Life Technologies. The oligonucleotides used for priming the cDNA synthesis were complementary to the $3^{\prime}$ untranslated region of the human, rat, or mouse GluR7 transcript to ensure highest specificity. cDNA aliquots were used as a template for standard PCR amplifications to obtain RT-PCR products covering the human and rat T/G and G/A sites or the mouse C/T site. TAQ2000 DNA polymerase (Stratagene, La Jolla, CA) was used for the amplification reactions. The RT-PCR primers were designed to amplify over at least one intron/exon border to avoid the amplification of genomic DNA sequences frequently present as contamination in total RNA preparations. To obtain genomic PCR fragments for the analysis of the T/G and G/A sites in the human GluR7 or rat GluR7 genes, we performed PCR reactions on genomic DNA. One of the PCR primers used was always complementary to intronic sequences to ensure gene specificity during amplification. GluR7 gene-specific exonic primers were used to analyze the $\mathrm{C} / \mathrm{T}$ polymorphism in the mice genome. When necessary, RT-PCR products or genomic PCR fragments were subcloned, and inserts were sequenced.

Identification and detection of GluR7 polymorphisms. Nucleotide variations at the $T / G, G / A$, or $C / T$ site in human, rat, or mouse GluR7 cDNA (mRNA) or in corresponding genomic DNAs were analyzed with a cycled primer extension assay with dideoxy terminators, as described in detail by
Schiffer and Heinemann (1999). ${ }^{32} \mathrm{P}$-end-labeled primers complementary to sequences upstream or downstream of the polymorphic nucleotide sites are hybridized to RT-PCR fragments or genomic PCR fragments and extended by using the Thermo-Sequenase DNA polymerase (Amersham Pharmacia Biotech, Piscataway, NJ) in the presence of dideoxy terminators. The length of the extended primers is determined by the type of nucleotide at the polymorphic nucleotide site. The extended primers were separated by electrophoresis in 15\% denaturing polyacrylamide $8 \mathrm{M}$ urea gels. Phosphorimaging analysis of the dried gels was used to quantify the relative amount of each allele in the analyzed DNA fragment fraction. Relative expression of GluR7 allelic mRNAs was assessed by calculating a ratio between the relative DNA fragment amounts that were detected for the two alleles.

Mouse whole-brain cDNA library 49 (C. Lai and S. Heinemann, unpublished data) was screened with a $0.7 \mathrm{~kb}$ cDNA probe corresponding to the $3^{\prime}$ end of the rat GluR7 cDNA to obtain sequence information of the mouse GluR7 cDNA. A $1.8 \mathrm{~kb}$ fragment was isolated, representing the $3^{\prime}$ half of the GluR7 cDNA. The sequence has been submitted to GenBank with the accession number AF245444. A transcribed nucleotide variation has been identified in the GluR7 gene between mouse stains $C B A / C a J$ and $129 / S v E v T a c$ by the Mutation Screener Kit from Ambion (Austin, TX). The nucleotide variation is localized at nucleotide position 1686 corresponding to the homologous rat GluR7 cDNA (A counting from A in the start codon of rat GluR7 cDNA). The $C B A / C a J$ mice strain contains a cytosine (C) at this position in contrast to the 129/SvEvTac strain that contains a thymine $(\mathrm{T})$.

Plasmids and site-directed mutagenesis. The human GluR7 cDNA clone was obtained from Merck Research Laboratories (San Diego, CA). The thymine residue at the $\mathrm{T} / \mathrm{G}$ site of this human GluR7(S310) cDNA clone, encoding the serine variant, was replaced by PCR-based site-directed mutagenesis with guanine to obtain the human GluR7(A310) cDNA, coding for the alanine isoform. The presence of the mutations and the correct sequence of the PCR-amplified DNA sequence were verified by DNA sequencing.

Electrophysiology. Transfection of human embryonic kidney-293 (HEK293) cells and whole-cell patch-clamp analysis of human GluR7(A310) or GluR7(S310) or rat GluR7(S310) receptor responses were performed as described previously (Schiffer et al., 1997).

\section{RESULTS}

\section{A genetic polymorphism underlies the observed variation of the human GluR7 cDNA sequence}

Two nucleotide variations found in cDNAs coding for the human GluR7 receptor (also known as EAA5) were postulated to result from RNA editing (Nutt et al., 1994). In the human GluR7 cDNA, guanine nucleotides were found at cDNA position 928, and adenine nucleotides were found at position 1055; these nucleotides did not match the reported human genomic sequences of thymine and guanine, respectively (Nutt et al., 1994). To characterize the proposed editing events in the human GluR7 receptor, we analyzed the $\mathrm{T} / \mathrm{G}$ and $\mathrm{G} / \mathrm{A}$ sites in human GluR7 mRNA, using the primer extension assay with ddTTP as the dideoxy terminator (Fig. $1 A$, lane 1). RT-PCR reactions were performed on human fetal whole brain total RNA that represented pooled RNAs derived from 13 brains. Primer extension analysis of the obtained RT-PCR products revealed a nucleotide variation at the $\mathrm{T} / \mathrm{G}$ site. Thus, we observed both a $21 \mathrm{bp}$ (T-containing) and $27 \mathrm{bp}$ (non-T-containing) extension product (Fig. $1 A$, lane 1 ; illustrated in $D$ ). The same result was obtained in two independent assays and is consistent with the result of Nutt et al. (1994). Phosphorimaging analysis determined that a thymine was present at the $\mathrm{T} / \mathrm{G}$ site in $\sim 92 \%$ of the analyzed fetal RT-PCR products. However, we could not detect a nucleotide variation at the G/A site in primer extension assays analyzing RT-PCR fragments containing the G/A site (data not shown).

In the rat GluR7 cDNA a guanine nucleotide was found at both corresponding sites (Bettler et al., 1992; Lomeli et al., 1992). Because RNA editing at the well characterized Q/R site in GluR2, GluR5, and GluR6 subunits proceeds to a similar extent in rat and humans (Seeburg, 1996), we next determined whether residues at the $T / G$ and G/A sites in the rat GluR7 cDNA also showed variability. We performed primer extension assays with ddTTP as a dideoxy terminator on RT-PCR products (see Materials and Methods; Schiffer and Heinemann, 1999). The cDNA products were obtained by amplifying a region that included the putative thymine/guanine $(\mathrm{T} / \mathrm{G})$ site at position 928 and the guanine/adenine (G/A) site at position 1055. The GluR7 cDNAs used as 
A

B

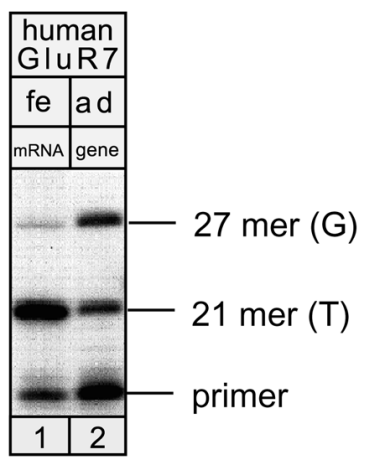

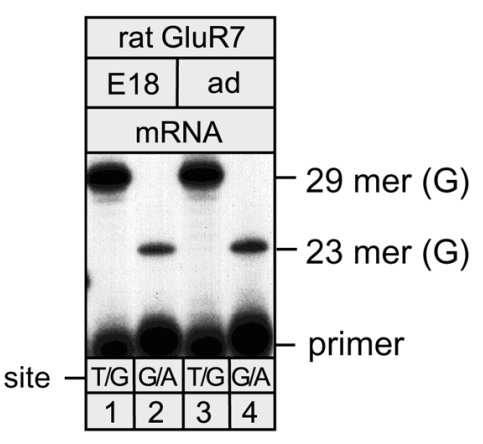

C

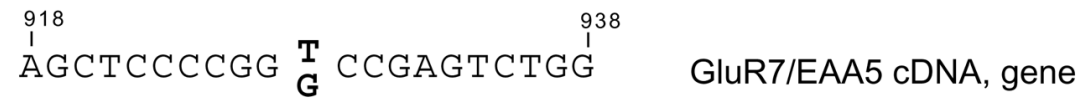

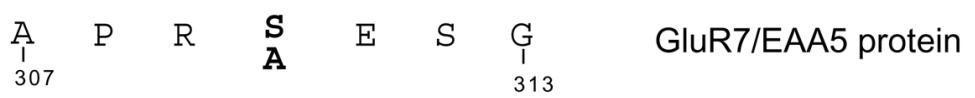

Figure 1. An exonic single nucleotide polymorphism in the gene GRIK3 encoding glutamate receptor subunit GluR7. $A$, Primer extension analyses with dideoxy terminator were performed to detect nucleotide variations at the $\mathrm{T} / \mathrm{G}$ site of the human GluR7 mRNA or gene. A ${ }^{32} \mathrm{P}$ labeled primer was annealed to GluR7specific RT-PCR (derived from cDNA) or genomic PCR products containing the $\mathrm{T} / \mathrm{G}$ site and was extended in the presence of ddTTP. Lane 1, T/G site in cDNA (total RNA derived from 13 fetal brains, fe). Lane 2, T/G site in gene (DNA derived from one adult brain, $a d$ ). The detection of two extended primer products, a 21- and 27-mer in both the cDNA and genomic DNA, indicates that the human GluR7 gene GRIK3 is polymorphic at the $\mathrm{T} / \mathrm{G}$ site. $B$, Primer extension analyses with dideoxy terminators were performed to detect potential editing events at the G/A and T/G site in rat brain GluR7 transcripts. ${ }^{32}$ P-labeled primers were mixed with GluR7-specific RT-PCR products derived from brain cDNA and were extended in the presence of the dideoxy terminator ddATP. Lanes 1, 3, Rat GluR7 $\mathrm{T} / \mathrm{G}$ site in embryonic (E18) and adult (ad) brain, respectively. Lanes 2, 4, Rat GluR7 G/A site in embryonic (E18) and adult $(a d)$ brain, respectively. If the nucleotide variations reported for these sites existed in rat, we would have detected two extended primer bands in each lane: a 29-mer and a 23-mer primer band for the $\mathrm{T} / \mathrm{G}$ site and a $23-\mathrm{mer}$ and a 20 -mer band for the G/A site. The detection of only one 29-mer band (T/G site, lanes 1, 3) and only one 23-mer band (G/A site, lanes 2, 4) indicated that the GluR7 mRNA sequence in the rat brain is not variable (edited) at these sites. $C$, Illustration of the genetic polymorphism identified in the GRIK3 gene (nucleotide position 928 in EAA5 cDNA; GenBank accession number U16127). Nucleotide and amino acid sequences of the region surrounding the T/G site in the GluR7 cDNA/GRIK3
${ }^{32} \mathrm{P}-\mathrm{GGCTGCAGGCAGCTCCC}$

${ }^{32} \mathrm{P}$ - GGCTGCAGGCAGCTCCCCGGTdd 17 mer primer

${ }^{32} \mathrm{P}-\mathrm{GGCTGCAGGCAGCTCCCCGGGCCGAGTdd}$
$21 \operatorname{mer}(\mathrm{T})$

$27 \operatorname{mer}(\mathrm{G})$

gene are shown. The variable nucleotide position found in the GluR7 gene and cDNA and the predicted alternating amino acids in the GluR7 receptor protein at amino acid position 310 are indicated in bold letters. Amino acid position number 1 corresponds to methionine in the GluR7 receptor precursor containing the signal peptide. $D$, Schematic illustration of the cycled primer extension assay with the dideoxy terminator ddTTP that was used to detect the $\mathrm{T} / \mathrm{G}$ nucleotide variation at the $\mathrm{T} / \mathrm{G}$ site of the human GluR7 receptor gene and mRNA. A radiolabeled primer (H7.PE.T/G), annealed to a genomic PCR or RT-PCR fragment, is extended in the presence of dCTP, dATP, dGTP, ddTTP, and Thermo-Sequenase DNA polymerase to a length of 21 nucleotides when a thymine $(T)$ is present or to a length of 27 nucleotides when a guanine $(G)$ is present at the GluR7 T/G site.

template for the amplifications were derived from embryonic (E18) and adult (ad) whole rat brain total RNA. Primer extension assays did not detect a nucleotide variation at either site in the rat GluR7 cDNA (Fig. 1B, lanes 1-4). The detection of only one 29-mer band $(\mathrm{G}$ at $\mathrm{T} / \mathrm{G}$ site; Fig. $1 B$, lanes 1,3$)$ and only one 23 -mer band $(\mathrm{G}$ at G/A site; Fig. $1 B$, lanes 2, 4 ) indicated that GluR7 mRNA sequences in the rat brain are not variable at these sites. These results demonstrate that the $\mathrm{T} / \mathrm{G}$ and $\mathrm{G} / \mathrm{A}$ sites in rat GluR7 transcripts are unlikely to be modified by RNA editing. We also amplified and subcloned four genomic DNA fragments from rat that included the $\mathrm{T} / \mathrm{G}$ or $\mathrm{G} / \mathrm{A}$ sites. In agreement with our primer extension assay results (and the sequence from the cloned cDNAs), we found only guanine residues in the GluR7 gene at these sites (data not shown).

To determine whether the nucleotide variation at the human GluR7 T/G site resulted from RNA editing or from a genetic polymorphism, we amplified genomic DNA sequences from the human GluR7 gene (GRIK3), which contained the GluR7 T/G site, and performed additional primer extension assays. The genomic DNA that we analyzed was derived from a single individual. In the genomic primer extension assay we found that thymine was incorporated in $\sim 50 \%$ of the extension products and that a nucleotide other than thymine was present in the rest of the extension products (Fig. 1A, lane 2). This observation is consistent with the interpretation that the individual was heterozygotic at this site in the GRIK3 alleles. Subcloned RT-PCR (cDNA) and genomic PCR products were sequenced to verify the results of the primer extension assays. As expected, guanine and thymine residues were found at the $\mathrm{T} / \mathrm{G}$ site in both the GluR7 cDNAs and the gene. Five genomic clones (derived from the single individual) were analyzed; two clones contained a thymine and three a guanine at the $\mathrm{T} / \mathrm{G}$ site. In 10 cDNA clones (derived from 13 pooled embryonic brains), one contained a guanine and nine contained a thymine at the $\mathrm{T} / \mathrm{G}$ site.

Primer extension assays with ddGTP as the dideoxy terminator were performed on genomic PCR fragments derived from an additional three individuals that were heterozygotic for the $\mathrm{T} / \mathrm{G}$ polymorphism. In all three samples we identified guanine in $\sim 50 \%$ of the extension products (data not shown). Additionally, we analyzed PCR fragments containing the G/A site derived from genomic DNA from 15 individuals. However, we could not detect a nucleotide variation in the GluR7 gene at the G/A site in three independent primer extension assays (data not shown).

These results demonstrate that the $\mathrm{T} / \mathrm{G}$ nucleotide variation in the GluR7 mRNA is caused by a bi-allelic polymorphism in the human GluR7 gene (GRIK3) and that the $\mathrm{T} / \mathrm{G}$ site contains no nucleotide types other than guanine or thymine. This exonic nucleotide variation predicts either a serine (S) or alanine (A) at position 310 (S/A site) in the N-terminal extracellular domain of the GluR7 receptor subunit (illustrated in Fig. $1 C$ ).

We were interested in determining the allele frequency and genotype distribution of the GluR7 $\mathrm{T} / \mathrm{G}$ polymorphism in the 


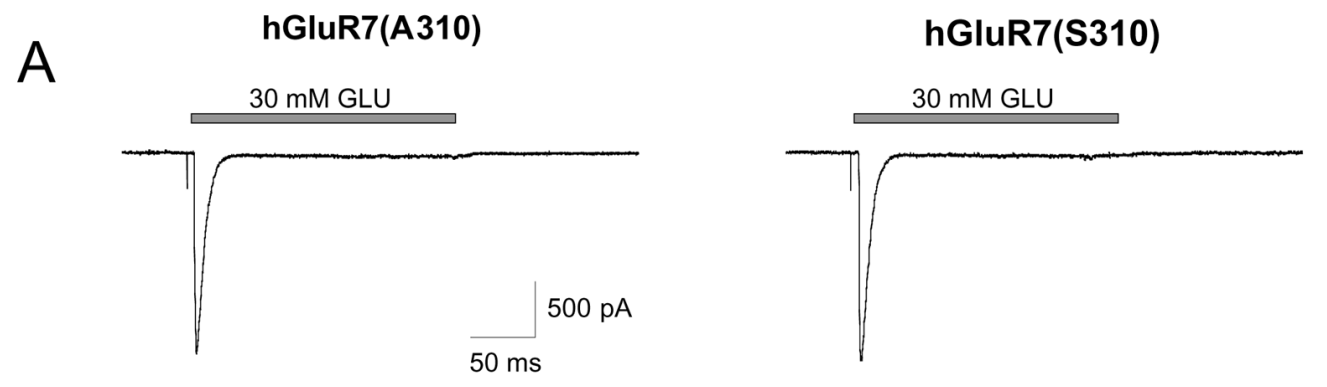

Figure 2. Electrophysiological characterization of the serine and alanine variants of the human GluR7 receptor after expression in HEK-293 cells. $A$, Example traces of currents evoked from homomeric human GluR7(A310) or GluR7(S310) receptors expressed in HEK-293 cells. Glutamate $(30 \mathrm{~mm})$ was applied for $100 \mathrm{msec}$; the holding potential was $-80 \mathrm{mV}$. $B$, Concentration-response curves for glutamate on human GluR7(A310), GluR7(S310), and rat GluR7(S310) receptors. Peak GluR7 responses at each concentration were normalized against a $30 \mathrm{~mm}$ L-glutamate response given $30 \mathrm{sec}$ before the test concentration. Data were fit to the Hill equation. Human GluR7, hGluR7; rat GluR7, rGluR7a.

human population. To address these questions, we analyzed the genomes of 35 healthy control Caucasians and determined the nucleotide identity at the $\mathrm{T} / \mathrm{G}$ site of each GluR7 allele. The results of these experiments are summarized in Table 1. The genotypes for each individual were obtained by performing primer extension assays with dideoxy terminators on genomic PCR fragments derived from these individuals (data not shown).

The frequency of the $\mathrm{T}$ and $\mathrm{G}$ allele among the group of 35 individuals ( 21 female and 14 male) was estimated as 0.70 and 0.30 , respectively (Table 1 ). Of the individuals, $42.8 \%$ were heterozygous for the $\mathrm{T} / \mathrm{G}$ polymorphism in the GRIK3 gene, $48.6 \%$ were homozygous for the T allele, and $8.6 \%$ were homozygous for the $\mathrm{G}$ allele (Table 1). The observed genotype distributions correlated well with the Hardy-Weinberg equilibrium, as predicted from the observed allele frequencies. These results suggest that the $T / G$ polymorphism in the GluR7 gene is common in the portion of the human population from which our genomic DNA was obtained (estimated heterozygosity, 0.428). Although we have not found evidence for a genetic polymorphism at the G/A site, we cannot exclude the existence of a rare genetic polymorphism at this site of the GRIK3 gene. The polymorphism at the T/G site of the GluR7 gene is the first example of a genetic polymorphism that affects the primary structure of a human ionotropic glutamate receptor subunit.

\section{Electrophysiological and pharmacological properties of the serine and alanine isoforms of the human GluR7 receptor}

We previously demonstrated that the rat GluR7 receptor subunit forms functional homomeric receptor channels with low sensitivity to glutamate (Schiffer et al., 1997). Because the T/G polymorphism occurs within the coding sequence of GluR7, we assayed for differences in the functional behavior of the human GluR7 receptor isoforms. Additionally, we were interested in comparing the functional properties of human GluR7 receptors with those of rat GluR7 receptors. The detected nucleotide variation at the $\mathrm{T} / \mathrm{G}$ site lies in a codon that codes for the amino acid serine when thymine is present or that codes for alanine when guanine is present (illustrated in Fig. 1C). The affected amino acid at position 310 is

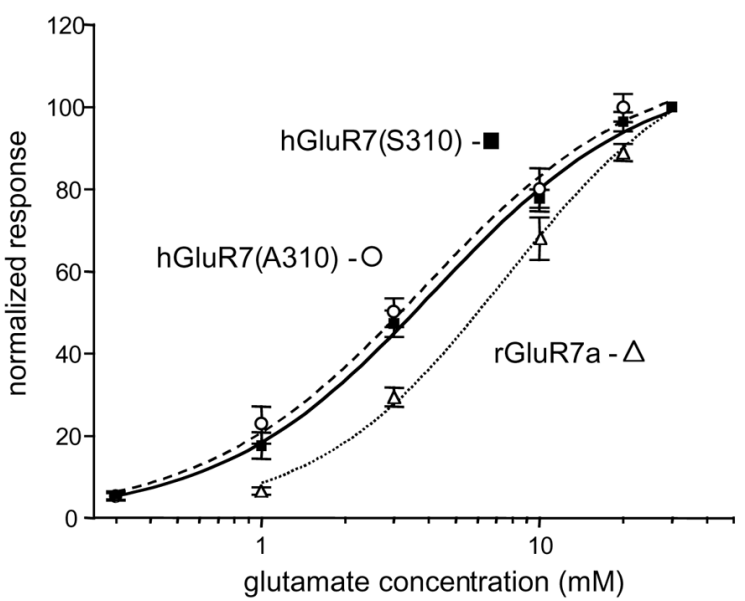

localized in the N-terminal extracellular domain of the GluR7 receptor protein (Nutt et al., 1994). This domain of glutamate receptors has been shown to affect receptor desensitization (Krupp et al., 1998) and to participate in ligand binding (Stern-Bach et al., 1994; Armstrong et al., 1998). The thymine residue at the T/G site of the human GluR7(S310) cDNA, encoding the serine variant, was replaced by PCR-based site-directed mutagenesis with guanine to obtain the human GluR7(A310) cDNA, coding for the alanine isoform. HEK-293 cells were transiently transfected with the human GluR7(A310) or GluR7(S310) cDNAs, and receptor currents evoked by fast application of glutamate $(30 \mathrm{~mm})$ were recorded in whole-cell patch-clamp configuration (Fig. $2 A$ ).

Homomeric human GluR7(A310) or GluR7(S310) receptors had similar functional properties (Fig. $2 A$ ). The mean peak amplitudes of glutamate-evoked currents for the human GluR7(A310) and GluR7(S310) receptors were $1.9 \pm 0.3 \mathrm{nA}$, with a $10-90 \%$ rise time of $1.4 \pm 0.2 \mathrm{msec}$, and $1.3 \pm 0.2 \mathrm{nA}$, with a $10-90 \%$ rise time of $1.3 \pm 0.1 \mathrm{msec}$, respectively. These data were not significantly different from each other or from that of the previously characterized rat GluR7a(S310) receptor $(1.1 \pm 0.2 \mathrm{nA}$ mean peak amplitude and $1.4 \pm 0.1 \mathrm{msec}$ rise time) (Schiffer et al., 1997). Glutamate-evoked currents from the human GluR7(A310), GluR7(S310), and rat GluR7a(S310) receptor desensitized with similar time courses $\left(\tau_{\text {des }}\right.$ of $7.1 \pm 0.7,6.3 \pm 0.4$, and $8.4 \pm 0.5 \mathrm{msec}$, respectively). Dose-response analyses of peak currents evoked by L-glutamate gave $\mathrm{EC}_{50}$ values for human GluR7(A310) and GluR7(S310) receptors of 4.1 and $3.8 \mathrm{~mm}$, respectively (Fig. 2B). Interestingly, the estimated $\mathrm{EC}_{50}$ values for these GluR7 receptor isoforms were lower than those of rat GluR7a(S310) receptors $\left(\mathrm{EC}_{50}=7.5 \mathrm{~mm}\right.$ in parallel experiments $)$, although the amino acid sequences of the mature rat and human GluR7(S310) receptor proteins differ by only eight amino acids. Consistent with this observation, Nutt et al. (1994) reported L-glutamate binding affinities that differed by approximately threefold between human and rat GluR7 receptors (Nutt et al., 1994).

Our results indicate that the replacement of serine 310 to alanine in the human GluR7 receptor does not affect receptor responses to glutamate. However, we cannot rule out the possibility that the 


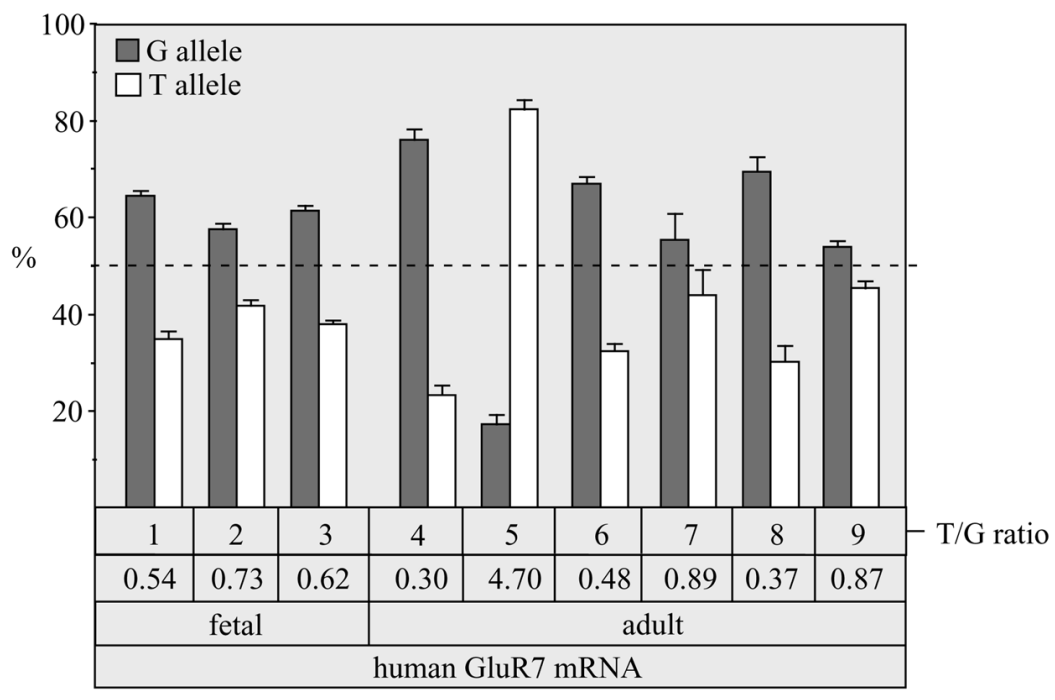

Figure 3. Unequal expression of GluR7 allelic mRNAs in human brains. Primer extension analysis with the dideoxy terminator ddTTP was performed to analyze the expression of GluR7 alleles in human brains (see Materials and Methods). Only individuals that were heterozygous for the $\mathrm{T} / \mathrm{G}$ polymorphism in the GluR7 gene are shown. The analysis combined nine total RNA samples obtained from nine individual human brains. ${ }^{32} \mathrm{P}$-labeled primers were annealed to GluR7-specific RT-PCR products obtained from each total RNA sample and were extended in the presence of the dideoxy terminator ddTTP. Primers were separated by gel electrophoresis and visualized by autoradiography. The detected products, a 21-mer (T allele-specific) and a 27-mer (G allele-specific), were quantified by phosphorimaging, and the $\mathrm{T} / \mathrm{G}$ ratio was determined. Each total RNA sample was analyzed three times to obtain the mean values and the SD shown in the bar graph. The bar graph shows the relative expression level of the GluR7 $\mathrm{T}$ and $\mathrm{G}$ allele in the brain samples (lanes 1-9). human alanine and serine variants of the GluR7 receptor have distinct functional behavior when expressed in the brain, perhaps in assemblies with additional subunits.

\section{GluR7 alleles are expressed unequally in human brains}

The human GluR7 gene has been mapped to chromosome one at region 1p34-33 (Puranam et al., 1993). Recent studies identified two tumor suppressor genes at this region, which are genomicimprinted. These genes code for the tumor suppressor protein $\mathrm{p} 73$ and NOEY2 and have been mapped to $1 \mathrm{p} 36$ and 1p31, respectively (Caron et al., 1995; Kaghad et al., 1997; Yu et al., 1999). Genomic imprinting is an epigenetic mechanism that silences the expression of an allele that is dependent on whether the inheritance of the allele is from the father (paternal) or the mother (maternal). We were interested in testing whether the human GluR7 gene (GRIK3) is affected by genomic imprinting, which would be manifested by unequal expression of GluR7 alleles in human brains. The $T / G$ polymorphism identified in the human GluR7 gene served in these experiments as a genetic marker to identify the differential expression of GluR7 alleles.

First, we analyzed the GluR7 allele expression levels in total RNAs isolated from brain tissue samples derived from nine individuals heterozygous for the $\mathrm{T} / \mathrm{G}$ polymorphism (three fetuses and six adults). The brain regions from which the samples were derived were not identified for these individuals. The total RNA isolated from each individual brain sample was reverse-transcribed with GluR7-specific primers, and the cDNAs were used as templates to obtain pools of RT-PCR products covering the T/G site of the GluR7 mRNA.

Each pool of RT-PCR products contained a mix of DNA fragments that had either a $T$ or $G$ at the $T / G$ site, because only individuals heterozygous for the $\mathrm{T} / \mathrm{G}$ polymorphism were analyzed. Individual RT-PCR product pools were used as template for the cycled primer extension assay with the dideoxy terminator ddTTP to determine the ratio between the T allele- and $\mathrm{G}$ allelederived PCR fragments in these pools. We have demonstrated previously that our assay is a sensitive method to quantify nucleotide variations in genomic PCR or RT-PCR fragment fractions (Schiffer and Heinemann, 1999). It was assumed that the relative proportion of the $\mathrm{T}$ or $\mathrm{G}$ allele in the analyzed DNA fragment pools reflected the relative expression level in the brain tissue samples. In our study the term "unequally expressed" was used when the relative GluR7 allele expression levels differed by $>1.2-$ fold from equal expression (based on the analysis of mouse GluR7 allele expression; see also Fig. 5 and Discussion).

Our assays revealed that GluR7 alleles were represented unequally in most of the RT-PCR product fractions. In six samples the estimated $\mathrm{T} / \mathrm{G}$ allele ratio varied between 0.30 and 0.73 , indicating a lower expression of the $\mathrm{T}$ allele as compared with the $\mathrm{G}$ allele
(Fig. 3, lanes 1-4, 6, 8). In contrast, one sample showed a $\mathrm{T} / \mathrm{G}$ ratio of 4.7, indicating a higher expression of the $\mathrm{T}$ allele as compared with the $\mathrm{G}$ allele (Fig. 3, lane 5). Two of the nine analyzed samples had a ratio of 0.89 and 0.87 , reflecting a nearly equal GluR7 allele expression (Fig. 3, lanes 7, 9). In summary, seven of the nine analyzed samples showed from 1.4- to 4.7-fold reduction in the expression levels of one GluR7 allele as compared with the second allele. All assays shown were repeated at least three times and gave reproducible results. The estimated SD for each analyzed sample ranged between 0.9 and $5.2 \%(n=3)$. Furthermore, repeating the analysis with independent cDNA synthesis and PCR reactions gave similar results (data not shown). Unequal expression as a result of polyploidy was excluded, because genomic PCR fragments derived from each sample had the expected $\mathrm{T} / \mathrm{G}$ ratio of $\sim 1$ (data not shown).

To analyze the unequal expression of GluR7 mRNA further, we analyzed additional human brain total RNA samples. We obtained total RNA samples isolated from the temporal lobes of neuropsychiatric patients matched for age and postmortem interval. Analyzing genomic DNA with the cycled primer extension assay identified twelve individuals that were heterozygous for the $T / G$ polymorphism in the GluR7 gene (data not shown). The corresponding 12 total RNA samples were analyzed as described before, and the relative GluR7 allele expression levels were determined (data not shown). Similar to our first observation, we detected unequal expression levels in most of the analyzed samples. Six samples showed a $\mathrm{T} / \mathrm{G}$ ratio between 0.52 and 0.72 , whereas four samples showed a $\mathrm{T} / \mathrm{G}$ ratio of $1.27,1.4,3.0$, and 5.8. Two samples showed a fairly equal expression of GluR7 alleles, with a $\mathrm{T} / \mathrm{G}$ ratio of 1.01 and 0.78 . These results indicate that the $T$ and $G$ allele of the GluR7 gene were expressed unequally in most of the human temporal lobes that we analyzed. The detection of unequal GluR7 allele expression in brain samples matched for brain region and age supported our initial observations and suggested that unequal GluR7 allele expression occurs in the majority of human brains.

\section{Regional diversity of unequal expression of allelic GluR7 mRNAs in individual brains}

The presence of mutations and genomic imprinting of the GluR7 gene are two possible mechanisms that account for our observation that unequal GluR7 allele expression occurred in human brain samples and that the difference between the GluR7 T allele and G allele expression levels varied over a wide range. To analyze this observation further, we determined the relative expression level of GluR7 alleles in various brain regions isolated from individual human brains. Genotyping of brain samples from adult individuals without disease history identified two brains (A and B) that were heterozygous for the $\mathrm{T} / \mathrm{G}$ polymorphism in the GRIK3 gene. Total RNA from frontal cortex, occipital cortex, parietal cortex, mesen- 
cephalon, cerebellum, basal ganglion, and thalamus were isolated and analyzed for their relative GluR7 allele expression levels by using RT-PCR in combination with the cycled primer extension assay (as described before). Interestingly, we found a large difference in the expression levels of GluR7 alleles in brain A. Variations also were observed between brain regions. The relative $\mathrm{T}$ and $\mathrm{G}$ allele expression levels varied between a factor 1.8- and 12.7-fold (Fig. 4A,B, lanes 1-6). In particular, the cerebellum expressed 12.7-fold less $\mathrm{G}$ allele than $\mathrm{T}$ allele. All other brain regions showed strong reduction of the $\mathrm{G}$ allele expression levels, with the exception of the frontal cortex where we detected a twofold higher expression level of the $\mathrm{G}$ allele as compared with the $\mathrm{T}$ allele. As a control, we analyzed the $\mathrm{T} / \mathrm{G}$ site in the genomic DNA from brain A. As expected, the $T$ and $G$ allele were represented equally in the genomic PCR product fraction (Fig. 4A,B, lane 7). These results also exclude the possibility that the $\mathrm{T} / \mathrm{G}$ polymorphism had a differential effect on the amplification efficiency of PCR products containing a $\mathrm{T}$ or $\mathrm{G}$ at the $\mathrm{T} / \mathrm{G}$ site. Our results indicate that GluR7 allele expression levels can differ in a human brain by at least 12.7-fold and that these differences can be variable among brain regions.

However, analyzing the same brain regions from a second brain (brain B) did not show significant differences in GluR7 expression levels. Most of the analyzed brain regions of brain B showed nearly equal expression levels of GluR7 alleles. Only three regions showed a $\mathrm{T} / \mathrm{G}$ ratio of under 0.63 (Fig. $4 C$, lanes $1-7$ ). Because brain $\mathrm{A}$ showed such a significant difference in GluR7 allele expression, we analyzed the relative GluR7 allele expression levels in cerebella from seven more brains heterozygous for the $\mathrm{T} / \mathrm{G}$ polymorphism (data not shown). No large differences in GluR7 allele expression levels were detected in the additional cerebella. Two cerebella showed a $\mathrm{T} / \mathrm{G}$ ratio of 0.52 and 0.62 . The other cerebella expressed the $\mathrm{T}$ and $\mathrm{G}$ allele at $\mathrm{T} / \mathrm{G}$ ratios from 0.85 to 1.2 (data not shown).

In 27 brain samples that showed unequal allele expression, the unequal expression of one GluR7 allele was not strictly correlated with a particular nucleotide type ( $T$ or $G$ ) found at the $T / G$ site, although the $\mathrm{T}$ allele was more frequently the GluR7 allele expressed at lower levels. Eighteen brain samples derived from 16 brains showed a lower expression of the $\mathrm{T}$ allele, in contrast to nine brain samples derived from six brains that showed a lower expression of the $\mathrm{G}$ allele (summarized in Table 2). On the basis of these observations, we considered genomic imprinting or mutations in the GluR7 mRNA as possible mechanisms that give rise to the unequal expression of GluR7 alleles in human brains.

\section{GluR7 alleles are not expressed unequally in mice F1 generation 129SvEvTac $\times$ CBA/CaJ mouse brains}

Because the genomic imprinting mechanism is conserved in most cases between human and mice (Falls et al., 1999), we tested whether the GluR7 gene showed unequal allele expression in a mouse model. To generate such a mouse model, we needed to identify a transcribed nucleotide variation between GluR7 genes from genetically divergent mice strains. Because the mouse GluR7 cDNA sequence was only partially available, we first screened a mouse brain cDNA library and cloned the $3^{\prime}$ half of the mouse GluR7 receptor cDNA (for details, see Materials and Methods). The GluR7 cDNA sequence $(1.8 \mathrm{~kb})$ that we obtained allowed us to screen mice strains for nucleotide variations in the GluR7 mRNA by using a mutation screener kit (see Materials and Methods; Goldrick et al., 1996).

We identified a silent nucleotide variation in the GluR7 open reading frame between the mouse strains $129 / S v E v T a c$ and $C B A$ / $C a J$ at mRNA nucleotide position 1686 (the adenosine in the start codon ATG is referred as nucleotide +1 , the numbering corresponding to the rat GluR7 cDNA sequence). The $C B A / C a J$ mouse strain contains a cytosine at this position, whereas the $129 / S v E v T a c$ strain contains a thymine. Male $129 / S v E v T a c$ mice were crossed with female $C B A / C a J$ mice and female $129 / S v E v T a c$ mice were crossed with male $C B A / C a J$ mice to obtain $\mathrm{F} 1$ generation mice that were heterozygous for the $\mathrm{C} / \mathrm{T}$ polymorphism. The relative GluR7 allele expression levels were analyzed in F1 generation mice at postnatal ages P3, P13, and P21. Total RNA was isolated from P3 whole brains, P13 cerebella, and P21 cortex, cerebella, and hippocampi. GluR7-specific primers were used to synthesize cDNA and to amplify RT-PCR products covering the $\mathrm{C} / \mathrm{T}$ site. The cycled primer extension assay with dideoxy nucleotide ddATP was used to quantify the relative expression level of GluR7 alleles and to analyze the mouse GluR7 gene (see Materials and Methods; Schiffer and Heinemann, 1999).

No differences in GluR7 allele expression levels were detected in our mouse brain samples (Fig. 5). The $\mathrm{C}$ and T allele of GluR7 were expressed equally in six tissue samples from two P21 mice brains, with estimated $\mathrm{C} / \mathrm{T}$ ratios varying between 0.97 and 1.07 (Fig. 5, lanes 3-8). Also, no difference in GluR7 allele expression level was detected in brain tissues from crosses in which the sex and genotype relationships were exchanged. F1 generation mice from crossing male $C B A / C a J$ mice with female $129 / S v E v$ Tac mice were denoted as $\mathrm{MC}$, in contrast to $\mathrm{FC}$ mice, which resulted from crossing female $C B A / C a J$ mice with male $129 / S v E v T a c$ mice (Fig. $5)$. In addition, similar results were obtained analyzing the brain tissue samples from mice at age P3 and P13 (data not shown). The detected $\mathrm{C}$ allele/ $\mathrm{T}$ allele ratios only varied between a factor 0.9 and 1.1. These results show that the GluR7 alleles in F1 generation mice, derived from crosses of $129 / S v E v T a c$ mice with $C B A / C a J$ mice, are not expressed unequally. In addition, these results demonstrate that in an isogenic genetic background GluR7 allele ratios can be detected, with our primer extension assay, without variations $>0.1$. Although it appears unlikely, we cannot rule out completely the possibility that the GluR7 receptor gene is imprinted genomically in mice with a genetic background that differs from that of $129 / C B A$ mice.

\section{DISCUSSION}

\section{An exonic genetic polymorphism accounts for the expression of GluR7 receptor variants}

We identified a common T/G polymorphism in the human GRIK3 gene (heterozygosity, 0.428), which codes for the glutamate receptor subunit GluR7. The exonic nucleotide variation predicts either a serine or alanine at position 310 (S/A site) in the first half of the $\mathrm{N}$-terminal extracellular domain of the receptor. The function of this domain is not well understood, but it may play a role in receptor assembly (Kuusinen et al., 1999; Leuschner and Hoch, 1999) or in determining functional properties. Our electrophysiological characterization of the alanine and serine isoforms of the human GluR7 receptors showed no difference in pharmacology, receptor desensitization and rise time (see Fig. 2), or in receptor assembly (data not shown). However, these results do not exclude the possibility that the $\mathrm{T} / \mathrm{G}$ polymorphism in the GRIK3 gene affects GluR7-mediated neurotransmission or that functionally different GluR7 receptor isoforms might be related to neurological disease.

\section{Polymorphic GluR7 genes reveal differentially expressed allelic GluR7 mRNAs in human, but not in mouse, brains}

Recent studies discovered that the tumor suppressor genes $p 73$ and NOEY2 are modulated by genomic imprinting (Kaghad et al., 1997; Yu et al., 1999). The $p 73$ and NOEY2 genes are mapped to the small arm of chromosome one at region p36.2-3 and p31, respectively. The vicinity of these genes to the GluR7 gene, which has been mapped to region 1p33-34 (Puranam et al., 1993), led us to investigate whether the GluR7 gene similarly is imprinted.

To address this question, we performed gene-specific RT-PCRs on total RNA isolated from 41 tissue samples, which were derived from 30 individual human brains. All 30 brains were identified as heterozygous for the $\mathrm{T} / \mathrm{G}$ polymorphism. The relative expression levels of GluR7 alleles were compared by performing cycled primer extension assays. These experiments detected unequal representation of the T allele and $\mathrm{G}$ allele in the RT-PCR fragment fractions, suggesting that the GluR7 alleles were expressed unequally in 
A
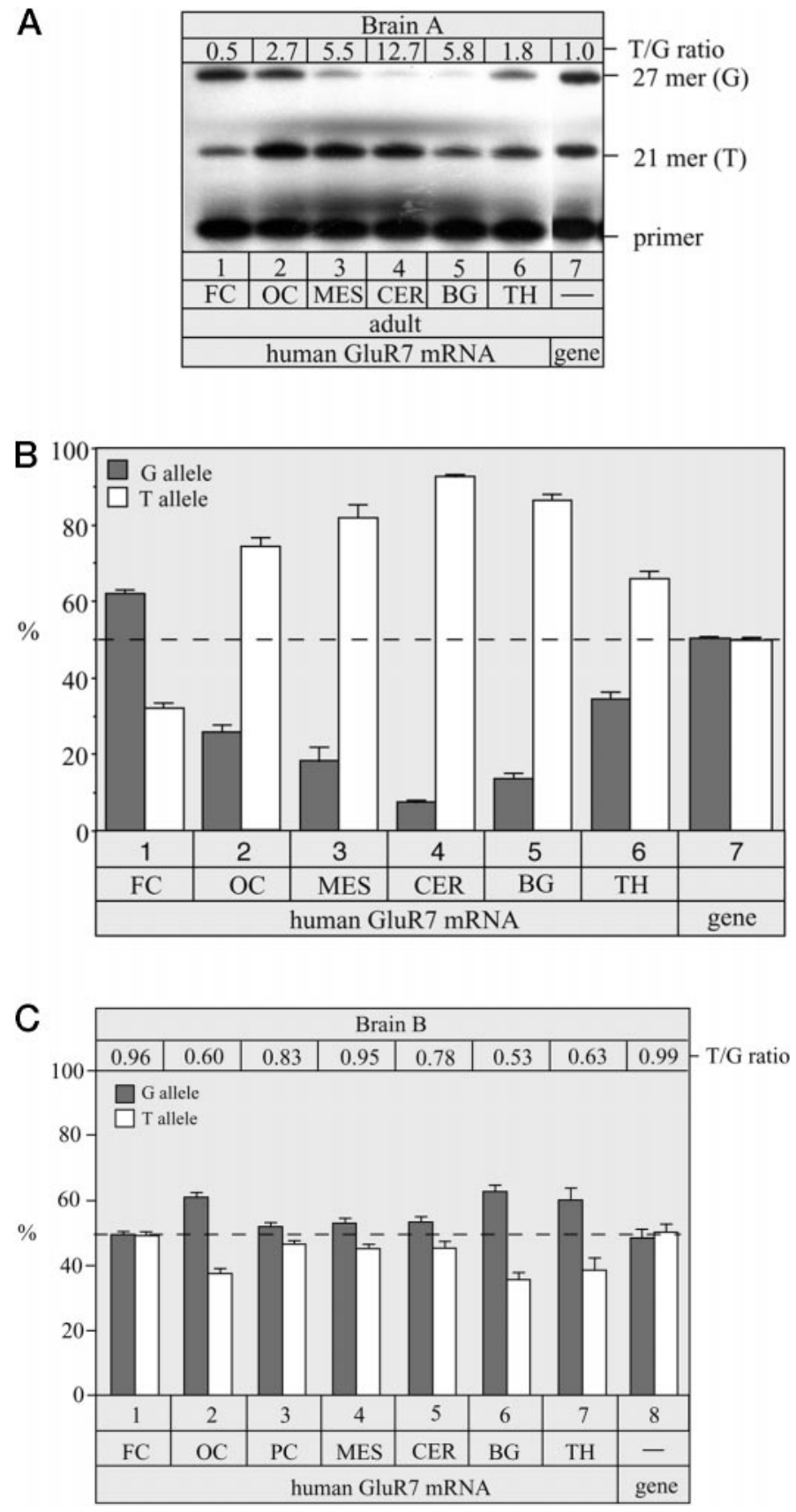

Figure 4. Varying unequal expression of GluR7 allelic mRNAs in brain regions from individuals. Primer extension analysis with the dideoxy terminator ddTTP was performed to analyze the expression of GluR7 alleles in various brain regions of individual human brains (see Materials and Methods). Only individuals that were heterozygous for the $T / G$ polymorphism in the GluR7 gene are shown. The analysis combined 13 total RNA samples obtained from two individual human brains. ${ }^{32} \mathrm{P}$-labeled primers were annealed to GluR7-specific RT-PCR products obtained from each total RNA sample and were extended in the presence of the dideoxy terminator ddTTP. Primers were separated by gel electrophoresis and visualized by autoradiography. The detected primer products, a $21-\operatorname{mer}(\mathrm{T}$ allele-specific) and a $27-$ mer ( $\mathrm{G}$ allele-specific), were quantified by phosphorimaging, and the $\mathrm{T} / \mathrm{G}$ ratio was determined. Each total RNA sample was analyzed three times to obtain the mean values and the SD shown in the bar graphs. $A$, Autoradiogram of brain A: analysis of tissue derived from frontal cortex $(F C)$, occipital cortex $(O C)$, mesencephalon $(M E S)$, cerebellum $(C E R)$, basal ganglia $(B G)$, and thalamus $(T H)$. The total RNA samples are derived from one individual brain (lanes 1-6). Also shown is an analysis of $\mathrm{T} / \mathrm{G}$ polymorphism in the GluR7 gene (lane 7). B, Bar graph showing the relative expression level of the GluR7 T and $\mathrm{G}$ allele in regions from brain A (lanes 1-6). Relative representation of $T$ and $G$ allele in genomic PCR fraction is shown in lane 7. C, Bar graph showing the relative expression level of GluR7 T and $\mathrm{G}$ allele in regions from brain B (lanes 1-7); also shown is the relative representation of $\mathrm{T}$ and $\mathrm{G}$ allele in the genomic PCR fraction obtained for brain B (lane 8).
Table 2. Summary of estimated GluR7 $\mathrm{T} / \mathrm{G}$ ratios, indicating unequal GluR7 allele expression level in 27 of 41 human brain samples

GluR7 allele expression

\begin{tabular}{lllc} 
level differences & $\mathrm{T} / \mathrm{G}$ ratios $<1$ & $\mathrm{~T} / \mathrm{G}$ ratios $>1$ & Total \\
\hline $0.8-1.2$-fold & - & - & 14 \\
$1.2-2.0$-fold & 16 & 2 & 18 \\
$2.0-12.7$-fold & 2 & $7^{a}$ & 9
\end{tabular}

${ }^{a}$ Four of seven brain samples derived from human brain A.

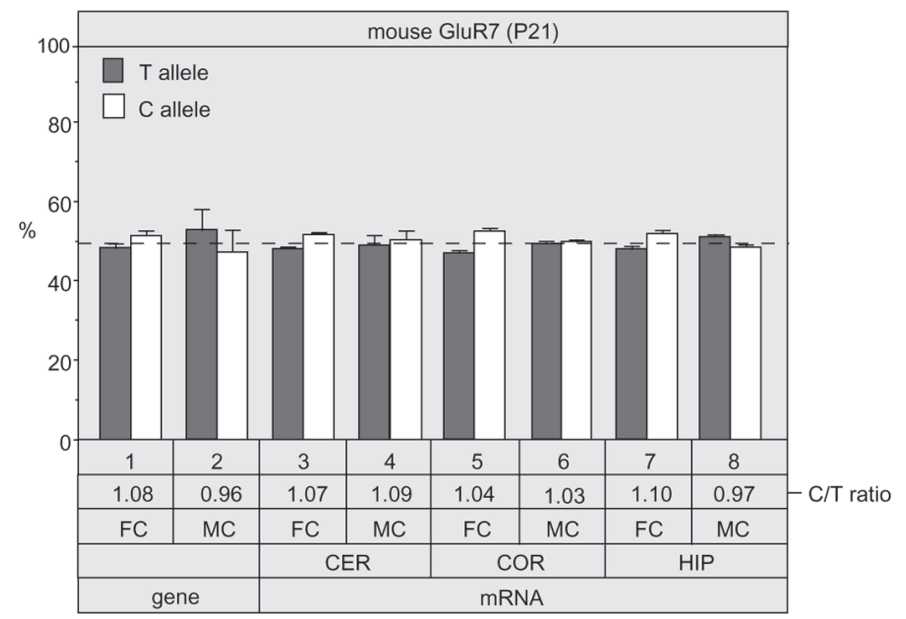

Figure 5. No unequal expression of GluR7 allelic mRNAs in brains from $129 / S v E v T a c \times C B A / C a J$ F1 generation mice. Primer extension analysis with the dideoxy terminator ddATP was performed to analyze the expression of GluR7 alleles in various brain regions of $129 / \mathrm{SvEvTac} \times \mathrm{CBA} / \mathrm{CaJ}$ F1 generation mice (see Materials and Methods). Only mice heterozygous for the $\mathrm{C} / \mathrm{T}$ polymorphism in the GluR7 gene are shown. ${ }^{32} \mathrm{P}$-labeled primers were annealed to GluR7-specific RT-PCR products obtained from each total RNA sample and were extended in the presence of the dideoxy terminator ddATP. Primers were separated by gel electrophoresis and were visualized by autoradiography. The detected primer products, a 20 -mer (T allele-specific) and a 22-mer (C allele-specific), were quantified by phosphorimaging, and the $\mathrm{C} / \mathrm{T}$ ratio was determined. Each total RNA sample was analyzed three times to obtain the mean values and the SD shown in the bar graph. The bar graph shows the relative expression level of the GluR7 $\mathrm{C}$ and $\mathrm{T}$ allele in brain regions from $\mathrm{P} 21$ mice (lanes $3-8$ ). Also shown is the relative representation of $\mathrm{C}$ and $\mathrm{T}$ allele in the genomic PCR fraction (lanes 1, 2). F1 generation mice from crossing male $C B A / C a J$ mice with female $129 / S v E v T a c$ mice are labeled $M C$, in contrast to FC-labeled mice, which resulted from crossing female $C B A / C a J$ mice with $129 / S v E v T a c$ mice. $C E R$, Cerebellum; COR, cortex; HIP, hippocampus.

several of the studied brains. GluR7 allele expression levels differed from 1.2- to 12.7-fold (Table 2).

The GluR7 alleles that were expressed at lower levels did not contain exclusively a thymine or guanine at the $T / G$ site. This observation excludes the possibility that the $\mathrm{T} / \mathrm{G}$ polymorphism in the GluR7 gene itself is causing a reduction in GluR7 allele expression level by affecting mRNA stability or RNA splicing. DNA fragments amplified from the $T$ and $G$ allele of the GluR7 gene always were represented in equal amounts in the genomic PCR product fractions. These results demonstrated that the analyzed genomes were diploid for the GluR7 gene and did not contain unequal amounts of the $\mathrm{T}$ or $\mathrm{G}$ allele in the genome. It is predicted that the observed reduction of GluR7 allele expression levels significantly alters the amount of GluR7 receptor protein that is synthesized in human brains. However, we were not able to test this prediction because of the absence of GluR7-specific antibodies.

The unequal representation of the $\mathrm{T}$ allele and $\mathrm{G}$ allele in the RT-PCR fragment fractions could have been the result of mutations or genomic imprinting of the human GluR7 gene. Genomic imprinting causes gene silencing that is dependent on the origin of inheritance. Imprinting is regulated during development and in a 
cell- and tissue-specific way (Latham, 1999). In some cases, imprinting of human genes has been described as a sporadic occurrence of unequal allele expression, accompanied by variability in allele expression levels (Xu et al., 1993; Jinno et al., 1994; Bunzel et al., 1998). The genetic heterogeneity of the human genome has been suggested as a major cause for this observed polymorphic imprinting. For example, silencing of the serotonin receptor subunit gene HTR2A has been detected in only four of 18 tested individuals (Bunzel et al., 1998); the insulin growth factor 2 receptor gene $I g f 2 r$ was found partially or complete silenced in only three of 14 fetuses (Xu et al., 1993). Expression of the homologous mouse genes that encode the IGFII-R and 5-HTR2A proteins was subject to allele-specific silencing in mouse populations (Barlow et al., 1991; Kato et al., 1998). Mouse strain-dependent developmental relaxation of imprinting of the endogenous mouse gene $K_{v}$ Iqt1 also has been observed (Jiang et al., 1998). The results of these studies indicate that the imprinting efficiency is dependent on the genetic background.

It seemed possible that human GluR7 genes were imprinted polymorphically. We detected differences in GluR7 allele expression levels (more than twofold differences) only sporadically in nine brain samples. Smaller differences (twofold or less than twofold) were observed more frequently in 18 brain samples (Table 2). The observation of unequal GluR7 allele expression can be explained by the heterogeneity of the genome in the human population and/or cell type and tissue-specific imprinting.

Allele-specific methylation or chromatin conformation may be involved in the maintenance of parental origin-specific expression of imprinted genes (for review, see Kelsey and Reik, 1998). However, because GluR7 mRNA is expressed predominantly in the CNS, we were unable to determine the parental influence on unequal expression of human GluR7 alleles. Furthermore, the inconsistency in GluR7 allele expression in human brains and the lack of sufficient tissue prevented us from studying methylation or chromatin conformation of GluR7 alleles. Therefore, we could not obtain conclusive evidence from analysis of human genes that the GluR7 gene was imprinted. However, in a follow-up study, we obtained data that indicated linkage between the GluR7 gene and a neurological disorder and suggested that the GluR7 gene or a close locus is imprinted genomically (our unpublished data).

As an alternate way of testing whether GluR7 genes were imprinted, we turned to an analysis of mouse GluR7 genes. In most, but not all, studied cases, an imprinted human gene also is imprinted in mice (Falls et al., 1999). Furthermore, analyzing genomic imprinting of genes in mice models avoids imprinting differences caused by heterogeneity of the genetic background. We therefore generated a mouse model to study the GluR7 allele expression. We identified a transcribed cytosine (C)/thymine (T) nucleotide variation in the GluR7 gene between $129 /$ SvEvTac and $C B A / C a J$ mice strains. Both strains were crossed to obtain $\mathrm{F} 1$ generation mice heterozygous for this $\mathrm{C} / \mathrm{T}$ polymorphism. We did not detect differences in relative GluR7 allele expression levels in $C B A / C a J$ mice and therefore did not find support for genomic imprinting of GluR7 in our mouse model (see Fig. 5). It should be noted, however, that the lack of evidence for genomic imprinting of the GluR7 gene in these mice does not eliminate the possibility that the human gene is imprinted. Human $\mathrm{GABA}_{\mathrm{A}}$ receptor subunit genes, specifically $G A B R B 3, G A B R A 5$, and $G A B R G 3$, were found to be imprinted in human tumor tissue (Kubota et al., 1994), but not in mice (Nicholls et al., 1993; Culiat et al., 1994). The imprinting status of these genes also was studied with somatic cell hybrids containing isolated human chromosomes. One study reported imprinting of these $\mathrm{GABA}_{\mathrm{A}}$ receptor genes (Meguro et al., 1997), in contrast to another study that did not detect evidence for genomic imprinting (Gabriel et al., 1998).

Our experiments with mice served a purpose peripheral to testing the imprinting hypothesis; that is, they allowed us to determine the variation observed between GluR7 allele expression levels in an isogenic genetic background. On the basis of this variation observed in our assays, we defined the term "unequal expression" to be a ratio of expression levels of GluR7 alleles that differed by $>1.2$-fold from the ideal expected ratio of 1.0.

Because of the lack of evidence for genomic imprinting of the GluR7 gene in $C B A / C a J$ mice, we also have to consider the possibility that the unequal GluR7 expression levels in human brains were the result of genetic alterations in the GluR7 gene itself. A correlation between gene alterations and differences in allele expression levels has been studied intensively in the disease neurofibromatosis type 1 (NF1; Hoffmeyer et al., 1994, 1995; Cowley et al., 1998). Unequal expression of NF1 alleles (from 2.0- to 20-fold) was detected frequently in neurofibromatosis samples and was correlated to the presence of gene mutations (Hoffmeyer et al., 1994, 1995; Cowley et al., 1998). Interestingly, unequal expression of NF1 alleles in tissues from one individual varied between 1.8- and fourfold among the tissue regions (Cowley et al., 1998). Therefore, it also is possible that the GluR7 gene in humans carries sporadic gene mutations that affect the apparent relative allele expression levels. The unequal expression of GluR7 alleles (see, for example, brain A, Fig. 4) therefore might arise in individuals carrying such mutations. The smaller differences in expression (up to twofold) could reflect genetic alterations in GluR7 alleles or modifier genes that have a minor impact on GluR7 allele expression level.

In summary, our results suggest that the human GluR7 gene either is affected by genomic imprinting or carries sporadic mutations that cause unequal allele expression. It will be interesting to analyze further the structure and function of the human GluR7 gene to distinguish between these possibilities.

\section{REFERENCES}

Armstrong N, Sun Y, Chen GQ, Gouaux E (1998) Structure of a glutamate receptor ligand-binding core in complex with kainate. Nature 395:913-917.

Barlow DP, Stoger R, Herrmann BG, Saito K, Schweifer N (1991) The mouse insulin-like growth factor type-2 receptor is imprinted and closely linked to the Tme locus. Nature 349:84-87.

Bettler B, Egebjerg J, Sharma G, Pecht G, Hermans-Borgmeyer I, Moll C, Stevens CF, Heinemann S (1992) Cloning of a putative glutamate receptor: a low affinity kainate-binding subunit. Neuron 8:257-265.

Bunzel R, Blumcke I, Cichon S, Normann S, Schramm J, Propping P, Nothen MM (1998) Polymorphic imprinting of the serotonin-2A (5HT2A) receptor gene in human adult brain. Brain Res Mol Brain Res 59:90-92.

Caron H, Peter M, van Sluis P, Speleman F, de Kraker J, Laureys G, Michon J, Brugieres L, Voute PA, Westerveld A (1995) Evidence for two tumor suppressor loci on chromosomal bands 1p35-36 involved in neuroblastoma: one probably imprinted, another associated with $\mathrm{N}$-myc amplification. Hum Mol Genet 4:535-539.

Choi DW (1988) Glutamate neurotoxicity and diseases of the nervous system. Neuron 1:623-634.

Choi DW, Maulucci-Gedde M, Kriegstein AR (1987) Glutamate neurotoxicity in cortical cell culture. J Neurosci 7:357-368.

Cowley GS, Murthy AE, Parry DM, Schneider G, Korf B, Upadhyaya M, Harper P, MacCollin M, Bernards A, Gusella JF (1998) Genetic variation in the $3^{\prime}$ untranslated region of the neurofibromatosis 1 gene: application to unequal allelic expression. Somat Cell Mol Genet 24:107-119.

Coyle JT, Puttfarcken P (1993) Oxidative stress, glutamate, and neurodegenerative disorders. Science 262:689-695.

Culiat CT, Stubbs LJ, Montgomery CS, Russell LB, Rinchik EM (1994) Phenotypic consequences of deletion of the $\gamma 3, \alpha 5$, or $\beta 3$ subunit of the type A $\gamma$-aminobutyric acid receptor in mice. Proc Natl Acad Sci USA 91:2815-2818.

Dingledine R, Borges K, Bowie D, Traynelis SF (1999) The glutamate receptor ion channels. Pharmacol Rev 51:7-61.

Falls JG, Pulford DJ, Wylie AA, Jirtle RL (1999) Genomic imprinting: implications for human disease. Am J Pathol 154:635-647.

Gabriel JM, Higgins MJ, Gebuhr TC, Shows TB, Saitoh S, Nicholls RD (1998) A model system to study genomic imprinting of human genes. Proc Natl Acad Sci USA 95:14857-14862.

Goldrick MM, Kimball GR, Liu Q, Martin LA, Sommer SS, Tseng JY (1996) NIRCA: a rapid robust method for screening for unknown point mutations. Biotechniques 21:106-112.

Hoffmeyer S, Assum G, Kaufmann D, Krone W (1994) Unequal expression of NF1 alleles. Nat Genet 6:331.

Hoffmeyer S, Assum G, Griesser J, Kaufmann D, Nurnberg P, Krone W (1995) On unequal allelic expression of the neurofibromin gene in neurofibromatosis type 1 . Hum Mol Genet 4:1267-1272.

Hollmann M, Heinemann S (1994) Cloned glutamate receptors. Annu Rev Neurosci 17:31-108.

Jiang S, Hemann MA, Lee MP, Feinberg AP (1998) Strain-dependent 
developmental relaxation of imprinting of an endogenous mouse gene, Kvlqt1. Genomics 53:395-399.

Jinno Y, Yun K, Nishiwaki K, Kubota T, Ogawa O, Reeve AE, Niikawa N (1994) Mosaic and polymorphic imprinting of the WT1 gene in humans. Nat Genet 6:305-309.

Kaghad M, Bonnet H, Yang A, Creancier L, Biscan JC, Valent A, Minty A, Chalon P, Lelias JM, Dumont X, Ferrara P, McKeon F, Caput D (1997) Monoallelically expressed gene related to p53 at 1p36, a region frequently deleted in neuroblastoma and other human cancers. Cell 90:809-819.

Kato MV, Ikawa Y, Hayashizaki Y, Shibata H (1998) Paternal imprinting of mouse serotonin receptor $2 \mathrm{~A}$ gene $\mathrm{Htr} 2$ in embryonic eye: a conserved imprinting regulation on the $\mathrm{RB} / \mathrm{Rb}$ locus. Genomics 47:146-148.

Kelsey G, Reik W (1998) Analysis and identification of imprinted genes. Methods 14:211-234.

Krupp JJ, Vissel B, Heinemann SF, Westbrook GL (1998) N-terminal domains in the NR2 subunit control desensitization of NMDA receptors. Neuron 20:317-327.

Kubota T, Niikawa N, Jinno Y, Ishimaru T (1994) GABA $_{\mathrm{A}}$ receptor $\beta 3$ subunit gene is possibly paternally imprinted in humans. Am J Med Genet 49:452-453.

Kuusinen A, Abele R, Madden DR, Keinanen K (1999) Oligomerization and ligand-binding properties of the ectodomain of the $\alpha$-amino- 3 hydroxy-5-methyl-4-isoxazole propionic acid receptor subunit GluRD. J Biol Chem 274:28937-28943.

Latham KE (1999) Epigenetic modification and imprinting of the mammalian genome during development. Curr Top Dev Biol 43:1-49.

Leuschner WD, Hoch W (1999) Subtype-specific assembly of $\alpha$-amino-3hydroxy-5-methyl-4-isoxazole propionic acid receptor subunits is mediated by their N-terminal domains. J Biol Chem 274:16907-16916.

Lipton SA, Rosenberg PA (1994) Excitatory amino acids as a final common pathway for neurologic disorders. N Engl J Med 330:613-622.

Lomeli H, Wisden W, Kohler M, Keinanen K, Sommer B, Seeburg PH (1992) High-affinity kainate and domoate receptors in rat brain. FEBS Lett 307:139-143.

McNamara JO (1993) Excitatory amino acid receptors and epilepsy. Curr Opin Neurol Neurosurg 6:583-587.

Meguro M, Mitsuya K, Sui H, Shigenami K, Kugoh H, Nakao M, Oshimura $M$ (1997) Evidence for uniparental, paternal expression of the human

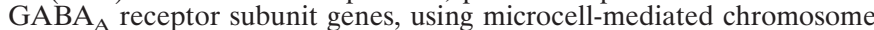
transfer. Hum Mol Genet 6:2127-2133.

Mulle C, Sailer A, Perez-Otano I, Dickinson-Anson H, Castillo PE, Bureau I, Maron C, Gage FH, Mann JR, Bettler B, Heinemann SF (1998)
Altered synaptic physiology and reduced susceptibility to kainateinduced seizures in GluR6-deficient mice. Nature 392:601-605.

Nicholls RD, Gottlieb W, Russell LB, Davda M, Horsthemke B, Rinchik EM (1993) Evaluation of potential models for imprinted and nonimprinted components of human chromosome 15q11-q13 syndromes by fine-structure homology mapping in the mouse. Proc Natl Acad Sci USA 90:2050-2054

Nutt SL, Hoo KH, Rampersad V, Deverill RM, Elliott CE, Fletcher EJ, Adams SL, Korczak B, Foldes RL, Kamboj RK (1994) Molecular characterization of the human EAA5 (GluR7) receptor: a high-affinity kainate receptor with novel potential RNA editing sites. Receptors Channels 2:315-326.

Olney JW (1980) Excitotoxic mechanisms of neurotoxicity. In: Experimental and clinical neurotoxicology (Spencer P, Shaumberg HH, eds), pp 272-294. Baltimore: Williams and Wilkins.

Puranam RS, Eubanks JH, Heinemann SF, McNamara JO (1993) Chromosomal localization of gene for human glutamate receptor subunit-7. Somat Cell Mol Genet 19:581-588.

Schiffer HH, Heinemann SF (1999) A quantitative method to detect RNA editing events. Anal Biochem 276:257-260.

Schiffer HH, Swanson GT, Heinemann SF (1997) Rat GluR7 and a carboxy-terminal splice variant, GluR7b, are functional kainate receptor subunits with a low sensitivity to glutamate. Neuron 19:1141-1146.

Seeburg PH (1996) The role of RNA editing in controlling glutamate receptor channel properties. J Neurochem 66:1-5.

Sprengel R, Seeburg PH (1995) Ionotropic glutamate receptors. In: Ligand- and voltage-gated ion channels (North AR, ed), pp 213-263. Boca Raton: CRC.

Stern-Bach Y, Bettler B, Hartley M, Sheppard PO, O'Hara PJ, Heinemann SF (1994) Agonist selectivity of glutamate receptors is specified by two domains structurally related to bacterial amino acid-binding proteins. Neuron 13:1345-1357.

Weiss JH, Yin HZ, Choi DW (1994) Basal forebrain cholinergic neurons are selectively vulnerable to AMPA/kainate receptor-mediated neurotoxicity. Neuroscience 60:659-664.

Xu Y, Goodyer CG, Deal C, Polychronakos C (1993) Functional polymorphism in the parental imprinting of the human IGF2R gene. Biochem Biophys Res Commun 197:747-754.

Yu Y, Xu F, Peng H, Fang X, Zhao S, Li Y, Cuevas B, Kuo WL, Gray JW, Siciliano M, Mills GB, Bast Jr RC (1999) NOEY2 (ARHI), an imprinted putative tumor suppressor gene in ovarian and breast carcinomas. Proc Natl Acad Sci USA 96:214-219. 